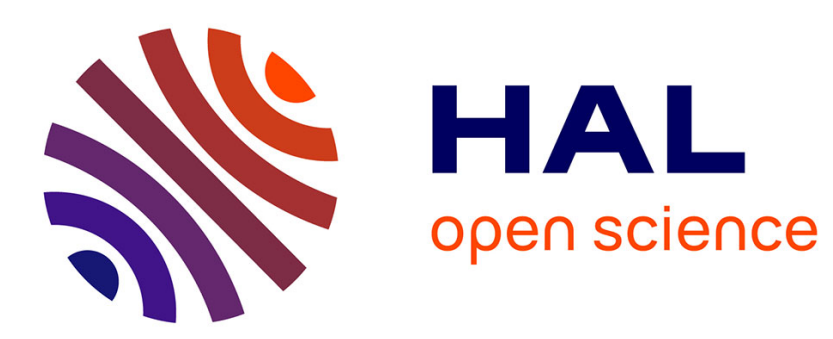

\title{
Epibator insularis, a New Species of Scincid Lizard from l'île Walpole, New Caledonia
}

Ross Sadlier, Leo Debar, Mikhail Chavis, Aaron Bauer, Hervé Jourdan, Todd Jackman

\section{- To cite this version:}

Ross Sadlier, Leo Debar, Mikhail Chavis, Aaron Bauer, Hervé Jourdan, et al.. Epibator insularis, a New Species of Scincid Lizard from l'Île Walpole, New Caledonia. Pacific Science, 2019, 73 (1), pp.143-161. 10.2984/73.1.7 . hal-02496785

\section{HAL Id: hal-02496785 https://hal.science/hal-02496785}

Submitted on 16 Mar 2020

HAL is a multi-disciplinary open access archive for the deposit and dissemination of scientific research documents, whether they are published or not. The documents may come from teaching and research institutions in France or abroad, or from public or private research centers.
L'archive ouverte pluridisciplinaire HAL, est destinée au dépôt et à la diffusion de documents scientifiques de niveau recherche, publiés ou non, émanant des établissements d'enseignement et de recherche français ou étrangers, des laboratoires publics ou privés. 


\title{
Epibator insularis, a New Species of Scincid Lizard from l'Île Walpole, New Caledonia ${ }^{1}$
}

\author{
Ross A. Sadlier, ${ }^{1,5}$ Léo Debar, $^{2,4}$ Mikhail Chavis, ${ }^{3}$ Aaron M. Bauer, ${ }^{3}$ \\ Hervé Jourdan, ${ }^{2}$ and Todd R. Fackman ${ }^{3}$
}

\begin{abstract}
A new species of skink in the genus Epibator is described from Île Walpole, a small, isolated, raised vegetated limestone platform, $200 \mathrm{~km}$ ESE of southern New Caledonia. The new species is distinguished from its congeners Epibator nigrofasciolatus and E. greeri primarily by its coloration and pattern (both species), differences in scalation (greeri), and substantial genetic differentiation (nigrofasciolatus). The new species is the only extant endemic terrestrial vertebrate on Walpole. The island is small $\left(<1.7 \mathrm{~km}^{2}\right)$, and has a long history of past human occupation (over the last 2,500 years, including European-era exploitation for guano), resulting in degradation of the vegetation cover and introduction of invasive animal species, most significantly ants (Little Fire Ant, Yellow Crazy Ant) and rats (Pacific Rat). The species' very limited distribution in combination with the threats posed by invasive species place it at a level of risk sufficient to be considered as Critically Endangered under IUCN Red List criteria.
\end{abstract}

Keywords: Scincidae, Epibator, systematics, new species, island, conservation, Critically Endangered

Research into the systematics of the predominately endemic New Caledonian skink and gecko fauna over the past 20 years has significantly increased our understanding of the species richness and generic diversity of both lizard groups, an outcome of morphological and genetic investigation utilizing

\footnotetext{
${ }^{1}$ Australian Museum Research Institute, Australian Museum, Sydney, Australia.

${ }^{2}$ Aix-Marseille Université, Université d'Avignon, CNRS, IRD, IMBE (Institut Méditerranéen de Biodiversité et d'Ecologie marine et continentale), Centre IRD Nouméa - BP A5, 98848 Nouméa Cedex, New Caledonia.

${ }^{3}$ Department of Biology, 800 Lancaster Avenue, Villanova University, Villanova, Pennsylvania 19085, USA.

${ }^{4}$ 287, rue des Cocotiers, 98809 Mont-Dore, New Caledonia.

${ }^{5}$ Corresponding author

(e-mail: ross.sadlier@bigpond.com).
}

collections made through extensive field studies in the region during this period. The most significant contribution to the increase in species richness has come through the delineation of cryptic lineages within genera distributed on ultramafic surfaces of the massifs and ranges of the Grande Terre, the main island of New Caledonia. Most notably, these increases have been in the scincid genera Caledoniscincus (Sadlier et al. 2013, Sadlier, Whitaker et al. 2014), Marmorosphax (Sadlier and Bauer 2000; Sadlier et al. 2009), Nannoscincus (Sadlier et al. 2002, Sadlier, Bauer et al. 2004, Sadlier, Bauer et al. 2006), and Sigaloseps (Sadlier and Bauer 1999; Sadlier, Bauer et al. 2014), and in the diplodactylid genus Dierogekko (Bauer et al. 2006a). Other significant additions have come from the discovery of "novel" and clearly undescribed species such as the skink Kanakysaurus viviparus (Sadlier, Smith et al. 2004) and gecko Oedodera marmorata (Bauer et al. 2006b). Most of these recently described species have very small ranges, the product of a history of regional isolation at a small geographic scale, with microendemism being 
the emerging trend for the region's fauna (Caesar et al. 2017).

By comparison, the lizard fauna of the major satellite islands of the Grande Terre (Îles Belep and the Île des Pins), or the major outlying islands in the region (Îles Loyauté and Île Walpole) has, until recently, received little attention. The Îles Belep and the Île des Pins lie off the northern and southern end, respectively, of the Grande Terre, and both are essentially extensions of the main island's land surfaces with intervening areas now submerged. Field studies on the Île des Pins in 1992 (Bauer and Sadlier 1994) provided the first comprehensive overview of that island's lizard fauna, and was expanded between 2000 and 2003 with surveys of the outlying islets (Geneva et al. 2013). From these studies, two species were recognized as restricted to the Île des Pins island complex, the skink Celatiscincus euryotis (Sadlier, Smith etal.2006) and the gecko Rhacodactylus trachycephalus (Bauer et al. 2012), clearly demonstrating the potential for localized island endemism. The later rediscovery of the giant skink Phoboscincus bocourti in the Île des Pins region (Ineich 2009) also likely represents the presence of another localized island endemic, as does the recent discovery of a new skink genus under description (Sadlier, Deuss et al. 2019). Field studies undertaken on the Beleps in 2002 resulted in the discovery of a distinct species of crested gecko from the islands, Correlophus belepensis (Bauer et al. 2012), whose sister species $C$. ciliatus occurs on the adjacent Grande Terre (Bauer et al. 2012; Sanchez et al. 2015), and of a species of Dierogekko (Bauer et al. $2006 a$ ) from the region, further indicating island endemism to be a broadly ranging phenomena in the archipelago, at least on these stranded remnants of the Grande Terre, and later field studies in 2006 identified another species of Dierogekko endemic to one of the intervening islands between the Beleps and Grande Terre (Skipwith et al. 2014).

The Îles Loyauté lie approximately $100 \mathrm{~km}$ off the east coast of the Grande Terre, and are fossil coral reefs uplifted during the quaternary (Paris 1981). Walpole lies even further offshore, $\sim 200 \mathrm{~km}$ ESE of the southern tip of the Grande Terre, and is similar in structure to the Îles Loyauté in being a raised coral platform with a probable volcanic core (Sand 2004; Cluzel et al. 2012). The lizard fauna of the Îles Loyauté complex predominately comprises both species endemic to, but broadly distributed within, greater New Caledonia, and also representatives of genera with broader distributions in the Pacific Region, but which are only present in the territory on the Îles Loyauté and not on the Grande Terre (Sadlier et Bauer 1997; Daza et al.2015). The skink Emoia loyaltiensis, a member of a diverse genus with representatives widespread throughout the Pacific region, is strictly endemic to the Îles Loyauté, and the gecko Bavayia crassicollis is probably endemic as well (occasional specimens reported from the Île des Pins island group are likely the result of accidental human translocation-Geneva 2007; Geneva et al. 2013). The large gecko Gebyra georgpotthasti, recorded from Maré and Tiga islands in the Iles Loyauté, is a broader regional endemic, also occurring in southern Vanuatu (Flecks et al. 2012; Daza et al. 2015).

Île Walpole is the smallest and most remote of the larger outlying islands in the territory of New Caledonia, located $\sim 140 \mathrm{~km}$ to the east of the Île des Pins and $140 \mathrm{~km}$ SSE of Maré in the Îles Loyauté (Figure 1), with a surface area of $\sim 170$ hectares (Butaud and Jacq 2015). There is evidence of former occupation of the island by Melanesians dating back 2,500 years, and during the first half of the twentieth century it was intensively mined for guano, with up to 300 people living on the island (Sand 2004). It has been of particular interest to archeologists, because the island has gone through a period of discovery, long-term occupation(s), then abandonment that predates European occupation in the southwest Pacific. Walpole is also the first place in the archipelago where remains of extinct horned tortoises, Meiolania were found (Andrews 1922; Anderson 1925; Gaffney et al. 1984; Gaffney 1996). However, knowledge of the present day reptile fauna of the island is negligible, the only lizards reported being "un petit lézard gris non identifié" and "un scinque" (Rennevier and Cherrier 1991). In 2013, the IMBE Nouméa team (LD \& HJ) participated in a mission to inventory the invasive rodent and invertebrate fauna (particularly exotic ants) of Île Walpole, and to collect information on 


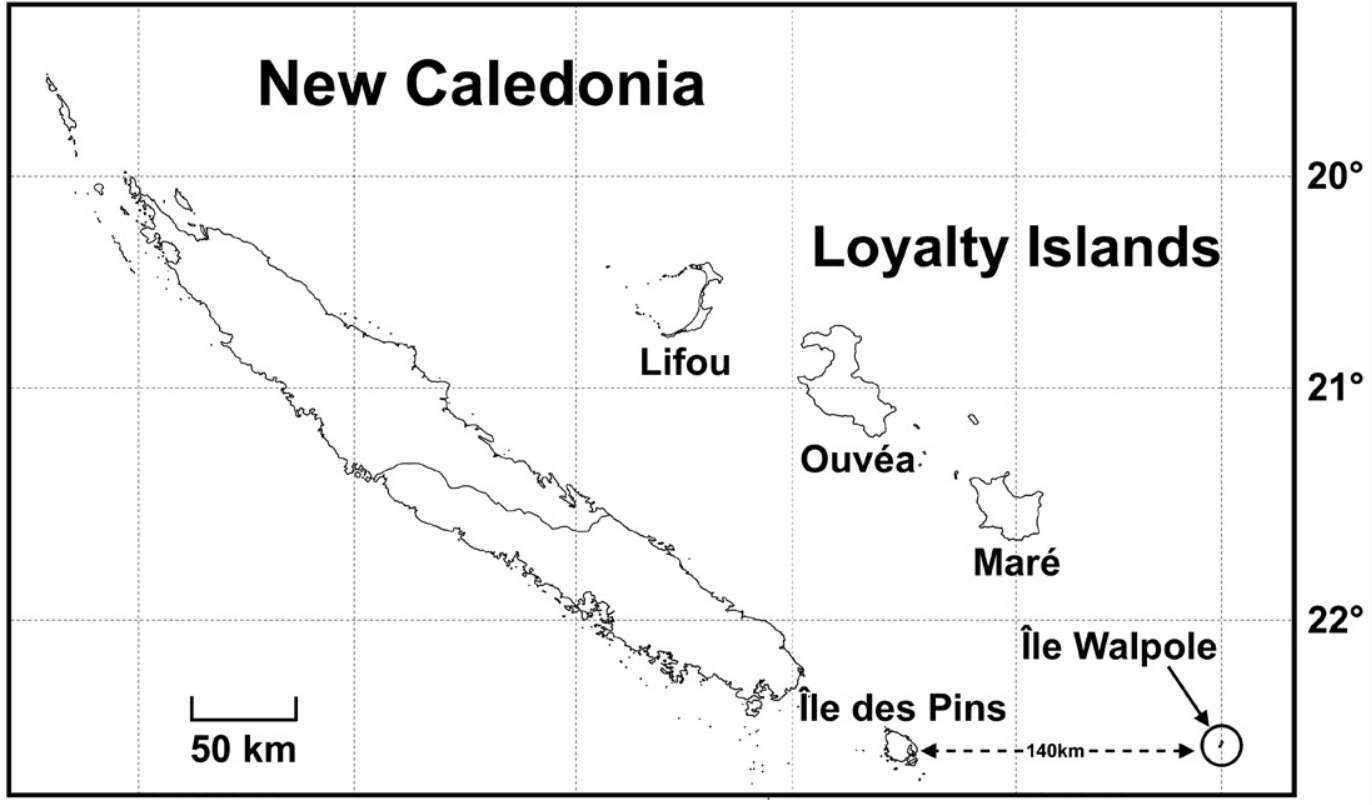

FIgure 1. Position of Île Walpole in the Pacific Ocean $\sim 140 \mathrm{~km}$ to the east of the Île des Pins off the southern end of New Caledonia.

the lizard fauna of the island (Debar et al. 2013). Among the lizards recorded was a species of skink in the genus Epibator, similar in overall morphology to E. nigrofasciolatus, a widespread generalist distributed across New Caledonia (Bauer and Sadlier 2000). The species was clearly different in coloration and a single individual was collected as a voucher of the species for further study and tail tips were taken from other individuals to assess the extent of genetic differentiation between the Walpole specimens and samples of E. nigrofasciolatus from throughout the Grande Terre and other outlying islands. The genetic data derived lends support to the differences found in coloration in identifying the Walpole Epibator as a species distinct from other members of the genus, and we here formally describe it as Epibator insularis n. sp.

\section{MATERIALS AND METHODS}

Abbreviations: Institutional abbreviations are as follows: Australian Museum (AMS), Sydney;
California Academy of Sciences (CAS); Institut Méditerranéen de Biodiversité et d'Ecologie marine et continentale (IMBE); Museum of Comparative Zoology, Harvard University (MCZ); Muséum National d'Histoire Naturelle (MNHN), Paris.

Morphological Comparisons: Measurements. Snout to vent length (SVL) - measured from tip of snout to caudal edge of anal scales; axilla to groin distance-measured from middle of base of forelimb to middle of base of hindlimb; forelimb to snout length-measured from tip of snout to middle of base of forelimb; hindlimb length-from middle of base of hindlimb to tip of fourth toe including nail; tail length-measured from caudal edge of anal scales to tip of tail, on complete original tails only. Body measurements (axilla to groin, forelimb to snout, hindlimb, and tail lengths) are expressed as percentages of snout to vent length in the taxon account. Sex was determined (in the case of the only specimen collected) by the presence of enlarged testes.

Scalation. Midbody scale rows (MBR): number of longitudinal scale rows around 
TABLE 1

Differences in scalation between the species of Epibator (data for E. greeri from Sadlier 1986 and data for $E$. nigrofasciolatus represents an expanded data set to that presented in Sadlier 1986 from throughout the region of Grande Terre including Île des Pins, and the Illes Loyauté)

\begin{tabular}{lccc}
\hline \hline & $\begin{array}{c}\text { E. insularis n. sp. } \\
n=1\end{array}$ & $\begin{array}{c}\text { E. nigrofasciolatus } \\
n=58\end{array}$ & $\begin{array}{c}\text { E. greeri } \\
n=1\end{array}$ \\
\hline MBR & 39 & $32-40(=36.3)$ & 34 \\
DSR & 91 & $80-95(=86.5)$ & 74 \\
FFS & $13-14$ & $13-17=15.7)$ & - \\
FFL & 18 & $18-25(=21.4)$ & - \\
FTS & 18 & $17-22(=19.6)$ & - \\
FTL & $28-30$ & $28-34(=31.6)$ & $24-27$ \\
\hline
\end{tabular}

body counted midway between axilla and groin; dorsal scale rows (DSR): number of scales in a row from first scale posterior to parietal scale to last scale at level of vent opening; fourth finger (FFS) and toe (FTS) scales: number of dorsal scales on fourth digit of manus and pes, distal scale contains claw, basal scale broadly contacts adjacent basal scale of third digit; fourth finger (FFL) and toe (FTL) lamellae: number of ventral scales on fourth digit of manus and pes, distal scale contains claw, basal scale is last largely undivided scale at, or proximal to, a point level with intersection of third and fourth digits. Bilateral scalation characters were scored on both sides and presented as such in the description of Epibator insularis n. sp. and for this species in Table 1, whereas the mean value for these characters is given for Epibator nigrofasciolatus in Table 1. Terminology for head scalation follows that adopted and illustrated by Sadlier (1986) and later refined and presented in detail by Sadlier (2010). Variation in coloration includes information on three additional individuals for which images but no vouchers exist (these were captured and released); two of these represent photographic images (Figures 4 and 5 ), the third a low-resolution video the quality of which is not suitable for reproduction here.

Intrageneric morphological comparisons with other members of the genus Epibator were limited given that the species from Walpole is known only from a single specimen and images of several others, and the species Epibator greeri is likewise known only from a single specimen and images of three other individuals.

Genetic Comparisons: We sampled 14 individuals of the Walpole species, 38 specimens of Epibator nigrofasciolatus from throughout the Grande Terre, Lifou, the Beleps and the Île des Pines, and 27 individuals representing 17 species in 11 endemic New Caledonian skink genera as outgroup taxa (for details and Genbank accession numbers, see Supplemental Online Material: Appendix S1). We also included two specimens of Cryptoblepharus novocaledonicus in the phylogenetic analyses to root the phylogenetic trees. Epibator greeri, which we believe to be closely related to $E$. nigrofasciolatus, was not included in the analysis because we have been unable to extract DNA from tissues from the holotype of this rare species (Smith et al. 2007).

Authors' Note: Supplemental materials available only on BioOne (http://www.bioone. org/).

We isolated genomic DNA from liver samples $(95 \%-100 \%$ ethanol) using the Qiagen DNeasy tissue extraction kit (Valencia, California). We used double-stranded PCR to amplify 4,454 aligned bases of mitochondrial (ND2, $1023 \mathrm{bp}$ ) and nuclear (RAG1, $981 \mathrm{bp}$; KIF24, 558 bp; EXPH5, 708 bp; BRCA2, 1,184 bp) gene sequence data using the primers listed in Table 2.

We used an Eppendorf Mastercycler thermocycler to amplify $25 \mu \mathrm{l}$ PCR reactions under several different annealing temperatures, and products were visualized with $1.5 \%$ agarose gel electrophoresis. We purified target products using AMPure magnetic bead PCR amplification kits (Agencourt Bioscience) and sequenced them with BigDye ${ }^{\circledR}$ Terminator v3.1 Cycle Sequencing Kits (Applied Biosystems). We purified sequencing reactions with a Cleanseq magnetic bead solution (Agencourt Biosciences) and generated sequences on an ABI3730xl DNA analyzer. We used negative controls to ensure the accuracy of sequences.

Phylogenetic analysis: We imported sequence data into Geneious 7.1 (Drummond et al. 2012) and assembled contig sequences from the sequenced fragments. We manually 


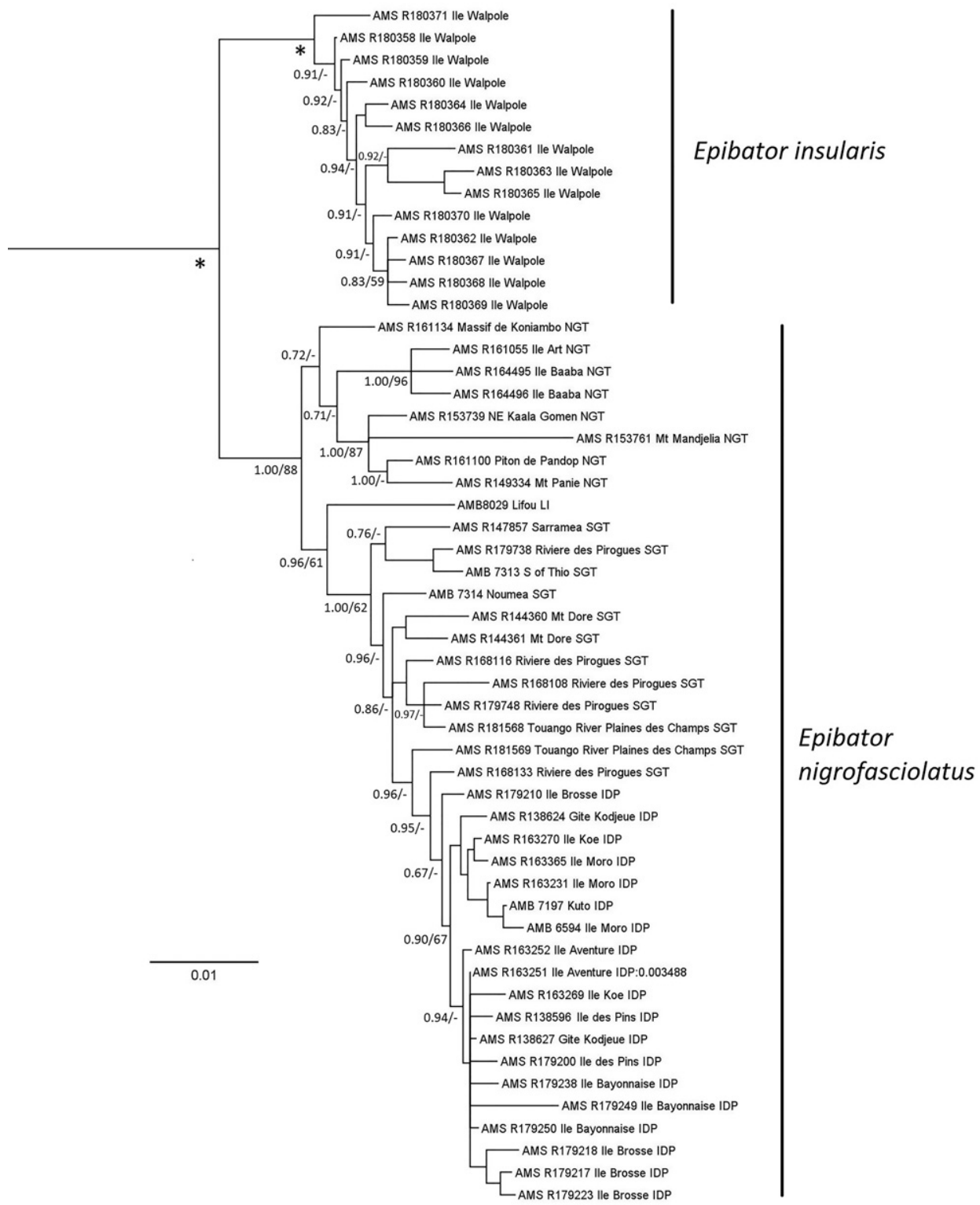

FIGURE 2. Bayesian Inference concatenated tree (ND2, RAG1, KIF24, BRCA2, EXPH5) for Epibator. Values at branches are PP/BS; an asterisk (*) indicates strong bootstrap and posterior probability support. SGT=southern Grande Terre, NGT = northern Grande Terre, Beleps and Baaba (northern islands), LI=Loyalty Islands (Îles Loyauté), $\mathrm{IDP}=$ Ille des Pins and surrounding islands.

corrected ambiguous or missing base pairs that resulted from poor quality signal at a locus and replaced unambiguous heterozygous loci in nuDNA sequences with corresponding IUPAC mixed base codes. Each gene alignment was generated using the Mafft Mutiple Alignment tool (Katoh et al. 2002) at default settings (gap penalty $=1.53$, offset value $=0.123$ ) and manually corrected for errors. Uncorrected pairwise genetic 

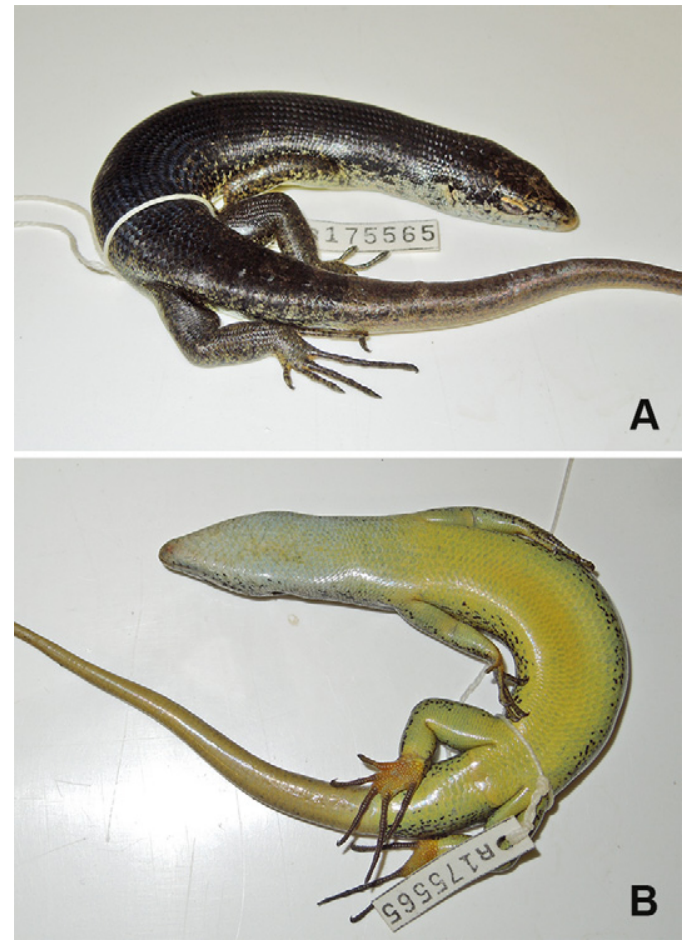

FIgURE 3. Dorsal view of the holotype of Epibator insularis n. sp. $(A)$ and ventral view $(B)$ just prior to preservation, clearly showing the lemon-yellow color to the underside of the body, limbs and tail, and lack of this coloration on the throat. distances within and between geographic groupings of Epibator were calculated for ND2.

We conducted analyses on the CIPRES Science Gateway servers (Miller et al. 2010). Maximum Likelihood (ML) was implemented in RaxML 7.2.6 (Stamatakis 2006) used with the optimal partitioning scheme and the General Time Reversible (GTR) model of evolution. Support was assessed with 1,000 bootstrap pseudoreplicates using a rapid algorithm implemented in RaxML (Stamatakis et al. 2008). Bayesian Inference (BI) was implemented in MrBayes 3.1.2 (Ronquist and Huelsenbeck 2003) using 20 million MCMC generations under four incrementally heated Markov chains for two independent runs. Trees were sampled every 1,000 generations and the first $25 \%$ of saved trees were discarded as burn in. Runs were combined in Logcombiner and convergence parameters were checked in Tracer v1.6 (Rambaut et al. 2007). Bootstrap values $\geq 70$ (ML) and posterior probabilities $\geq 0.95$ (BI) were considered to reflect high support.

To determine the appropriate evolutionary substitution model and the appropriate partitioning schemes for both individual and concatenated multigene datasets, we used PartitionFinder with the Bayesian Inference Criterion (Lanfear et al. 2014). Since

TABLE 2

Loci and primers used for the New Caledonian skinks with associated oligonucleotide sequences - source of primers as follows: (1) Macey et al. (1997); (2) Greenbaum et al. (2007); (3) Arevalo et al. (1994); (4) Portik et al. (2010); (5) Chavis (2016)

\begin{tabular}{lllr}
\hline \hline Gene & \multicolumn{1}{c}{ Primer } & Sequence & Source \\
\hline tRNA Met & Metf1 & AAGCTTTCGGGCCCATACC & 1 \\
ND2 & ND2f101 & CAAACACAAACCCGRAAAAT & 2 \\
tRNA Trp & Trpr3 & TTTAGGGCTTTGAAGGC & 2 \\
CO1 & CO1r1 & AGRGTGCCAATGTCTTTGTGRTT & 3 \\
RAG1 & RAG1sf1 & TTCAAAGTGAGATCGCTTGAAA & 4 \\
& RAG1r1200 & CCCTTCTTCTTTCTCAGCAAAA & 4 \\
KIF24 & KIF24f1 & SAAACGTRTCTCCMAAACGCATCC & 4 \\
& KIF24r1zebra & GCTGCTGRARCTGGTGATAAAGRCG & 5 \\
EXPH5 & EXPH5f1 & AATAAACTKGCAGCTATGTACAAAACAAGTC & 4 \\
& EXPH5NCskinkr4305 & TGGCGTTCRCGTTGCATTTTG & 5 \\
BRCA2 & BRCA2f984 & AACAGGTAGTCAGTTTGAMTTYACAC & 5 \\
& BRCA2r2315 & RTTGAAGYYTGAATGCYAGGTTTGAC & 5 \\
\hline
\end{tabular}


TABLE 3

Partition schemes, substitution model, and alignment length used for each locus in this study

\begin{tabular}{|c|c|c|c|c|c|}
\hline \multirow[b]{2}{*}{ Locus } & \multicolumn{2}{|c|}{ RaxML } & \multicolumn{2}{|c|}{ MrBayes } & \multirow[b]{2}{*}{$\begin{array}{l}\text { Length } \\
\text { (bp) }\end{array}$} \\
\hline & Partition & Substitution Model & Partition & Substitution Model & \\
\hline ND2 & $\begin{array}{l}\text { First codonSecond } \\
\text { codonThird } \\
\text { codontRNAs }\end{array}$ & $\begin{array}{l}\text { GTR+GGTR+GGTR } \\
+ \text { +GGTR+G }\end{array}$ & $\begin{array}{l}\text { First codonSecond } \\
\text { codonThird } \\
\text { codontRNAs }\end{array}$ & $\begin{array}{l}\text { GTR+GGTR+GGTR } \\
+ \text { GHKY+G }\end{array}$ & 1,023 \\
\hline RAG1 & $\begin{array}{l}\text { First codon }+ \text { second } \\
\text { codonThird codon }\end{array}$ & GTR+I+GGTR+I+G & $\begin{array}{l}\text { First codon }+ \text { second } \\
\text { codonThird codon }\end{array}$ & $\mathrm{HKY}+\mathrm{I}+\mathrm{GK} 80+\mathrm{I}+\mathrm{G}$ & 981 \\
\hline KIF24 & $\begin{array}{l}\text { First codon + second } \\
\text { codonThird codon }\end{array}$ & GTR+GGTR+G & $\begin{array}{l}\text { First codon + second } \\
\text { codonThird codon }\end{array}$ & $\mathrm{HKY}+\mathrm{GK} 80+\mathrm{G}$ & 558 \\
\hline EXPH5 & $\begin{array}{l}\text { First codon + second } \\
\text { codonThird codon }\end{array}$ & GTR+GGTR+G & $\begin{array}{l}\text { First codon + second } \\
\text { codonThird codon }\end{array}$ & $\mathrm{HKY}+\mathrm{GK} 80+\mathrm{G}$ & 708 \\
\hline BRCA2 & $\mathrm{BRCA} 2^{*}$ & $\mathrm{GTR}+\mathrm{G}$ & $\begin{array}{l}\text { First codonSecond } \\
\text { codon }+ \text { third codon }\end{array}$ & $\mathrm{HKY}+\mathrm{GGTR}+\mathrm{G}$ & 1,184 \\
\hline
\end{tabular}

* BIC in Partitionfinder found the best scheme for BRCA2 to have no partitions for models available to RAxML.

MrBayes has more possible evolutionary models available than RAxML the best estimated substitution models and partitioning schemes varied between the two analyses for each locus (Table 3 ). The GTR $+\Gamma$ model was used for each of the partitions under ML because modeling options are limited in RAxML. A complete list of models and the concatenated partitioning schemes used in MrBayes for the concatenated dataset is shown in Table 4.

TABLE 4

Partition scheme of concatenated datasets for Bayesian inference in MrBayes

\begin{tabular}{lll}
\hline \hline Partition & \multicolumn{1}{c}{ Scheme } & $\begin{array}{c}\text { Evolutionary } \\
\text { Model }\end{array}$ \\
\hline 1 & $\begin{array}{l}\text { EXPH5 first codon, KIF24 first } \\
\text { codon, KIF24 second codon, }\end{array}$ \\
RAG1 first codon, RAG1 second \\
codon \\
2 & $\begin{array}{l}\text { KIF24 third codon, RAG1 third } \\
\text { codon }\end{array}$ & K80+I+G \\
3 & $\begin{array}{l}\text { BRCA2 first codon, BRCA2 } \\
\text { second codon, EXPH5 second }\end{array}$ & GTR+I+G \\
& $\begin{array}{l}\text { codon } \\
\text { BRCA2 third codon, EXPH5 }\end{array}$ & GTR+G \\
5 & third codon & HKY+G \\
6 & ND2 first codon, tRNAs & GTR+G \\
7 & ND2 second codon & GTR+G \\
\hline
\end{tabular}

\section{RESULTS}

Molecular Results: Neither BI nor ML analyses of the single genes or concatenated dataset resolved generic level relationships among New Caledonian skinks, as was found in earlier studies (Smith et al. 2007; Ineich et al. 2014), although the monophyly of individual genera was well supported (not shown).

Within Epibator there was notable phylogeographic structure in ND2, with Île Walpole specimens forming a divergent sister lineage to the rest of the E. nigrofasciolatus. Uncorrected pairwise divergences of ND2 between the Ile Walpole specimens and all populations of $E$. nigrofasciolatus ranges from $4.6 \%$ to $14.1 \%$ and (Table 5), whereas distances among geographic groupings of $E$. nigrofasciolatus were lower (1.0-8.0\%). Within E. nigrofasciolatus there were well-supported subclades from the northern islands and southern New Caledonia (including the Île des Pins region) and the northern Grande Terre (exclusive of Koniambo). There was also strong support under BI, but not under ML, for the northern Grande Terre in its entirety and for the Île des Pins region alone.

RAG1 was the only nuclear gene that revealed any structure within Epibator, with a monophyletic Ile Walpole population (PP 1.00, BS 96). The remaining individual nuclear loci (KIF24, BRCA2, and EXPH5) 
TABLE 5

Uncorrected pairwise distances for ND2 between geographic groupings of Epibator nigrofasciolatus and E. insularis, data given as ranges

\begin{tabular}{lccccc}
\hline \hline & IDP & SGT & NGT & LI & BLP \\
\hline Ile Walpole & $0.053-0.090$ & $0.052-0.088$ & $0.046-0.122$ & $0.059-0.141$ & $0.049-0.081$ \\
IDP & & $0.010-0.079$ & $0.036-0.071$ & $0.039-0.080$ & $0.041-0.063$ \\
SGT & & $0.030-0.055$ & $0.034-0.058$ & $0.035-0.046$ \\
NGT & & & $0.034-0.043$ & $0.032-0.071$ \\
LI & & & & 0.043 \\
\hline
\end{tabular}

IDP = Ille des Pins and surrounding islands, SGT=southern Grande Terre, NGT=northern Grande Terre, LI=Loyalty Islands (Îles Loyauté), and BLP = Beleps and Baaba (northern islands).

yielded no well-supported pattern of relationship within Epibator, but also no strong incongruence with the relationships found in ND2 and RAG1. The concatenated dataset of all four nuclear loci and ND2 produced a tree that largely agreed with the relationships supported by ND2 and RAG1 (Figure 2). Both BI and ML strongly supported a monophyletic Île Walpole population as sister
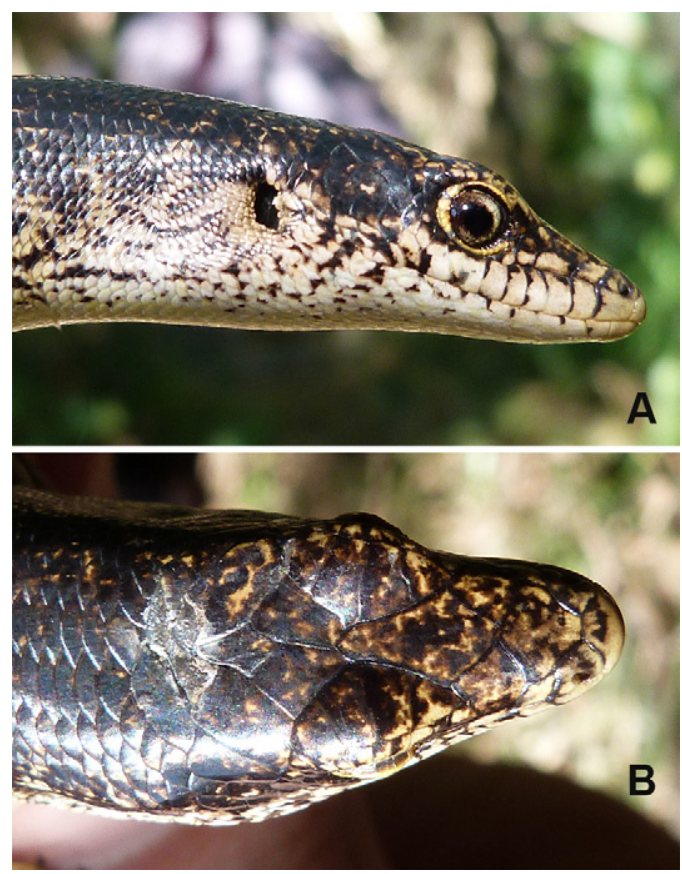

FIgURE 4. Images of a live individual of Epibator insularis $\mathrm{n}$. sp. with predominately dark coloration to the anterior part of the body $(A)$ and top of the head $(B)$. to all other E. nigrofasciolatus with similar topology and support for geographic groupings within the main (non-Walpole) clade. In both the ND2 and concatenated trees the sole sample from the Îles Loyauté (Lifou) was sister to the southern Grande Terre + Île des Pins, but with strong Bayesian support only.

\section{SYSTEMATICS}

The individual specimen of the species described here from Île Walpole has a suite of morphological apomorphies in scalation consistent with it being a member of the genus Epibator as defined by Sadlier et al. (2015) that includes: no distinct supranasal but the nasal scale with a prominent postnasal suture or crease; primary temporals usually two; upper labials eight (sometimes more), with the sixth subocular and contacting the lower eyelid, and the last divided by an oblique suture into an upper and lower scale; enlarged chinshields 4-5, first pair in broad contact medially, second pair in moderate contact, outer edge of first pair usually in partial contact with lower labials and the outer edge of the remaining chinshields separated from lower labials by one or two rows of smaller scales; basal-most dorsal scales of the toes divided. Within the endemic New Caledonian skink radiation the combination of scalation characters of eight or more upper labials with the last divided by an oblique suture and the separation of the chinshields from the lower labial scales by one or two rows of small intervening scales will distinguish Epibator from all other genera except Phoboscincus, from which it can be 
distinguished in having no distinct supranasal scale whereas the nasal scale of Phoboscincus is distinctly divided into three separate elements, the plesiomorphic condition. Further, Phoboscincus has fused frontoparietal scales and enlarged fang-like anterior teeth, two apomorphic character states not present in Epibator.

The genus Epibator is restricted to the territory of New Caledonia. The type species for the genus, Epibator nigrofasciolatus, is the most widespread member. It occurs across a broad range of habitats and elevations on the Grande Terre (Bauer and Sadlier 2000), and has been recorded from the major offshore island groups (Îles Belep, Île des Pins, and Îles Loyauté). By contrast, the other described member of the genus, Epibator greeri, was for over 30 years known only from specimens associated with the type from near Koumac in northwest Grande Terre (Sadlier 1986, Bauer and Sadlier 2000). However, in recent times individuals referable to this species have been photographed at three separate sites in the south of the main island (Sadlier pers. observ.), indicating the species is likely to be more widely distributed than previously thought. The distribution of the third species in the genus, Epibator insularis n. sp., described here, represents an extreme geographic outlier within the territory, in being known only from Île Walpole.

A comparison of scalation characteristics for the specimen from Ille Walpole with the holotype of Epibator greeri (see Sadlier 1986) for those characters for which data was available (Table 1) show substantial differences in values for midbody and dorsal scale rows, and nonoverlapping values for fourthtoe lamellae (see Diagnosis later). A comparison between the specimen from Walpole and a large series of Epibator nigrofasciolatus from across the species range $(n=58)$ for scalation characteristics (Table 1) show it to fall within the range of variation for E. nigrofasciolatus. As such, morphological differentiation between the species from Île Walpole and E. nigrofasciolatus is based primarily on differences in coloration (see Diagnosis later).

Epibator insularis Sadlier, Debar, Chavis, Bauer, Jourdan and Jackman n. sp.

Figure 3
Type Material: Holotype MNHN-

RA-2017.0100 (formerly AMS R.175568)

New Caledonia, Île Walpole, $22^{\circ} 36 / 13.00 / / \mathrm{S}$, $168^{\circ} 56 \prime$ 46.0/' E (datum WGS84 via

Google Earth), collected by Leo Debar 1522 May 2013.

Etymology: The epithet is an adjective in the masculine genitive meaning pertaining to an island and referring to its restriction to Île Walpole.

Diagnosis: Epibator insularis n. sp. can be distinguished from E. nigrofasciolatus and $E$. greeri, the only other members of the genus, by the combination of the following features of morphology: prefrontal scales narrowly separated; midbody scale rows 39; dorsal scale rows 91 ; a predominately dark color pattern on the anterior part of body, including the head, with little or no obvious transverse pattern to the dark dorsal coloration; and a pale lemon-yellow color to the ventral surface. Epibator insularis n. sp. is readily distinguished from E. greeri in features of scalation (Table 1) in having more midbody scale rows (39 versus 34) and more dorsal scale rows (91 versus 74), and in having the prefrontals narrowly separated versus contacting. It is further distinguished in coloration in having an obscure and irregular (versus bold and regular) arrangement to the dark markings across the dorsal surface of the body. In scalation the values for all meristic characters for Epibator insularis n. sp. fall within the range observed for a broad dataset of specimens of $E$. nigrofasciolatus (Table 1) and both species have the prefrontal scales separated, as such the two species are at this time are distinguished primarily on coloration. Epibator nigrofasciolatus from the Grande Terre typically have the dark markings on the dorsal surface of the anterior part of the body (either side of the shoulders) arranged to form regular transverse bars (Figure $6 A$ and $6 C$ ) and often interrupted medially by a dark streak down the center of the back (the dark transverse dorsal markings of nigrofasciolatus from the Îles Loyauté are present anteriorly although muted in some individuals but the dark median streak between the shoulders is usually absent). The head of Epibator nigrofasciolatus is typically uniform brown, ocasionally with 


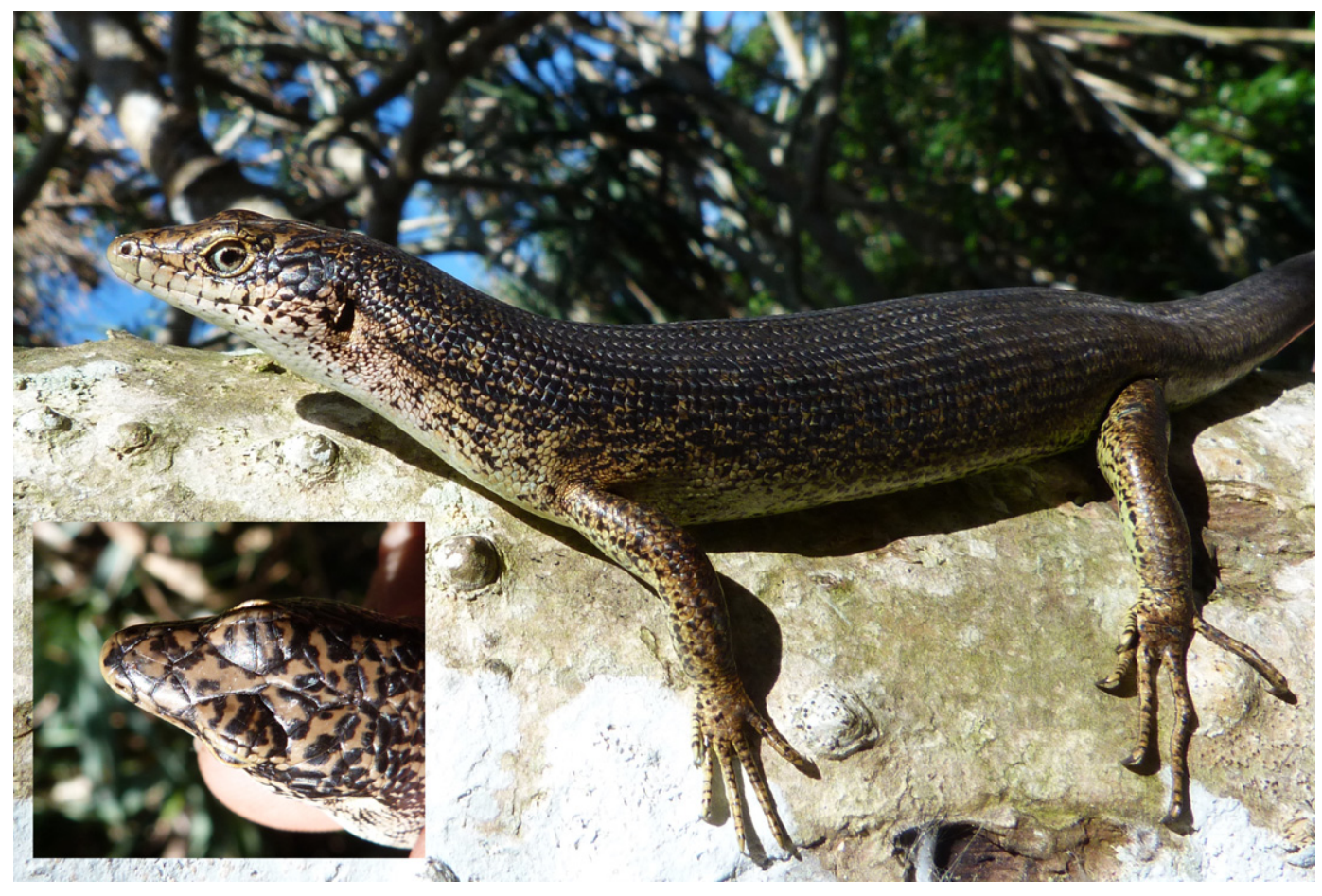

FIGURE 5. Images of live individual of Epibator insularis n. sp. with dark coloration on the body forming obscure transverse bands, and with an even distribution of black and brown coloration to the top of the head (inset).

some dark flecks at suture lines. By comparison, the area of the dorsal surface of the body either side of the shoulders in Epibatorinsularis n. sp. is predominately dark with little definable pattern of transverse bars anteriorly (Figures $3 A$ and 5) and no dark median streak between the shoulders, and most dorsal head shields have extensive dark markings (Figures $4 A, 4 B$, and 5 inset). Further, the ventral surface of Epibator nigrofasciolatus is typically lime-green in coloration (Figure 6B), although the intensity is variable and paler in some individuals, whereas the venter of E. insularis n. sp. is pale lemonyellow (Figure $3 B$ ) but also variable and paler in some individuals.

Description: Scalation and coloration is based on the holotype, an adult male.

Measurements. Snout to vent length (SVL) $105.5 \mathrm{~mm}$; distance from axilla to groin $58.8 \%$ of SVL; distance from forelimb to snout $37.9 \%$ of SVL; hindlimb length $37.9 \%$ of SVL; tail regenerated.
Scalation. Prefrontals large, narrowly separated; frontoparietals divided; interparietal distinct; parietals meet behind interparietal, parietals each bordered by a transversely elongate upper secondary temporal scale and nuchal scale; primary temporals two, the lower positioned partly between the last two upper labials; upper secondary temporal single; lower secondary temporal single; tertiary temporals two; lower postlabial scale divided such that two scales border the posterior edge of the divided last upper labial, upper postlabial a single scale bordering the upper posterior edge of the divided last upper labial and posterior edge of the secondary temporal; nasal scales moderately large and each with a distinct postnarial crease, narrowly to moderately separated and with what appears to be two small scales in the intervening area between (and separating the rostral scale from the frontonasal scale), although this may be an artifact of past 

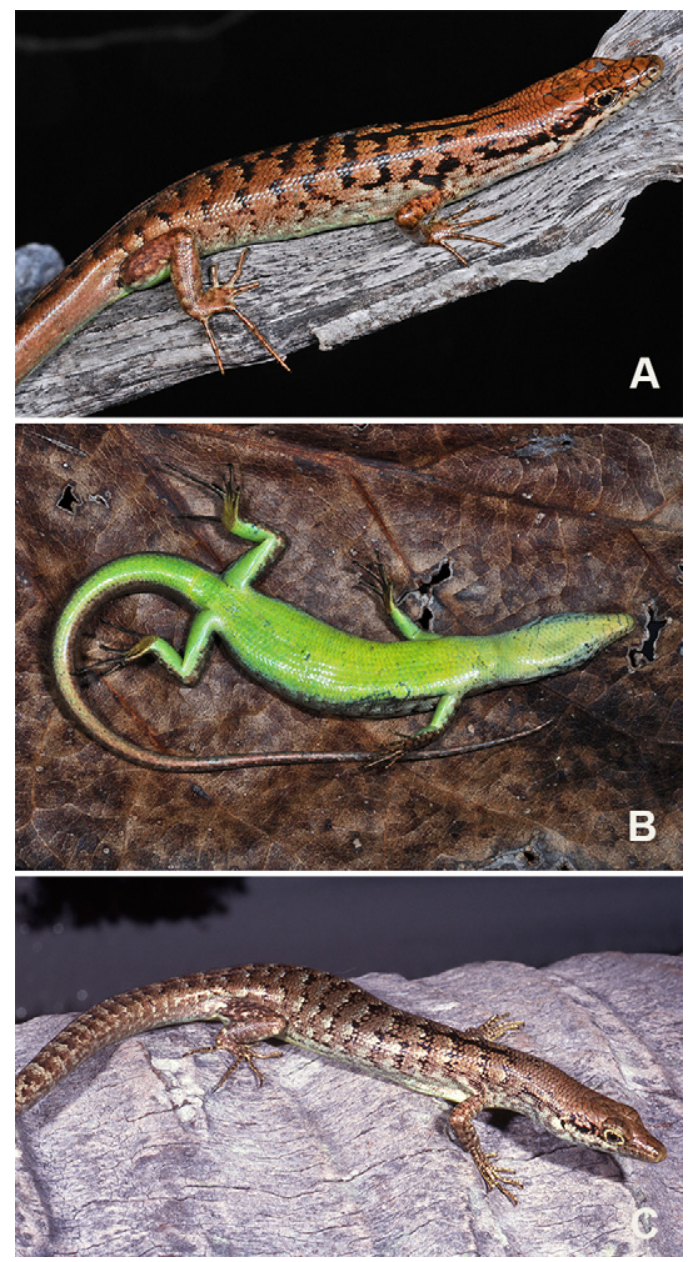

FIGURE 6. Images of live Epibator nigrofasciolatus from the Goro Plateau $(A$ and $B)$ in southern Grande Terre and from the Île des Pins $(C)$, the geographically nearest population to Epibator insularis n. sp..

damage to this area (see labial scales below); supraciliary scales $8 / 7$; upper labial scales $-/ 8$ (left side damaged anteriorly with a healedover injury but likely also eight), with the sixth subocular and contacting the lower eyelid; lower labials $8 / 8$, first two contacting postmental; enlarged chin shields $5 / 5$, members of first pair in broad contact, members of second pair separated by one scale, outer edge of first pair of chin scales mostly $(\sim 70 \%)$ in contact with the adjacent anterior lower labials, remaining chin shields separated from lower labials by one or two rows of smaller scales.
The lower eyelid has an obvious, centrally located, semitransparent disc. The ear opening is moderately large, with a single enlarged lobule uppermost on the anterior edge, and two to three smaller scales below.

Body scales are smooth; midbody scale rows 39; dorsal scale rows 91; scales on top of fourth finger 14/13; lamellae beneath fourth finger $18 / 18$; scales on top of fourth toe $18 / 18$, basal-most divided; lamellae beneath fourth toe $28 / 30$.

Coloration. The adult male holotype was photographed prior to preservation after having been thawed from a frozen state. The coloration at this time was predominately dark overall (Figure $3 A$ ), with a break in coloration on the side of the body where the dark color on the flanks is arranged in narrow rows (4-6 scales wide) with brown interspaces marked with scattered pale flecks. The head is similarly dark above at its rear, but with progressively larger areas of brown color on the snout and the dark color present as small to large blotches. The ventral surface posterior of the forelimbs, underside of the limbs and pale areas along the midlower lateral region were pale yellow (Figure $3 B$ ), but the underside of the head and throat cream with only a trace of pale yellow suffusion near the area of the forelimbs.

Variation. Images available for three live individuals (not vouchered) indicate the extent of dark coloration present on the head and body is variable. One (Figure 4) had a predominately dark coloration to the anterior part of the body and top of the head, similar to the holotype; another (Figure 5) some underlying definition in the arrangement of dark coloration on the anterior part of the body into transverse bands and with a more even proportion and distribution of brown color to the top of the head (Figure 5 inset); and another (not figured) a predominately muted brown coloration to the body with dark markings but with no definable pattern to these markings. All three additional individuals for which images were available showed a muted pale yellow ventral coloration on the underside of the chest abdomen and legs, and where it was able to be determined, an absence of yellow coloration to the underside of the 

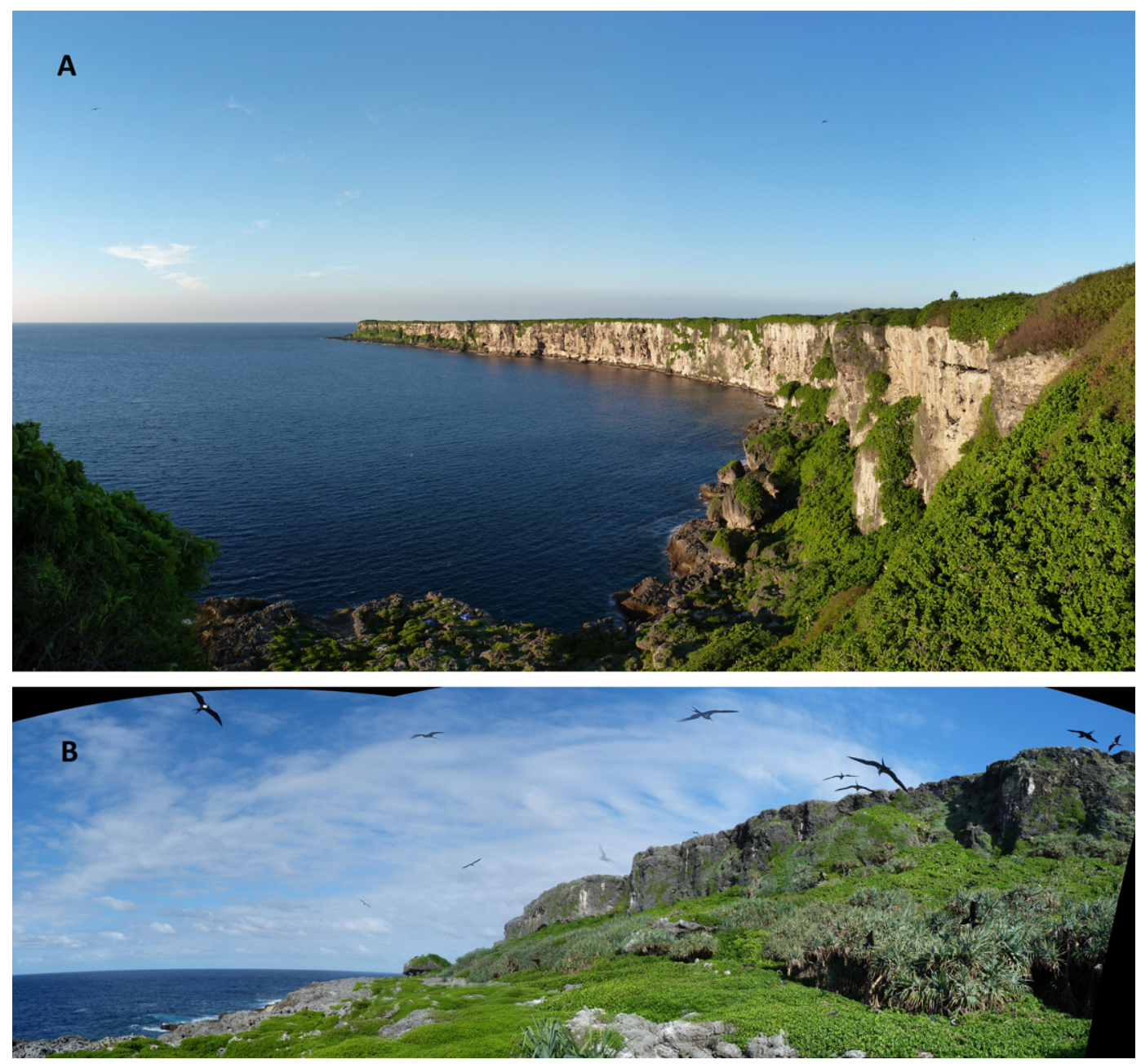

FIGURE 7. Île Walpole, showing elevated west coast plateau $(A)$ and more gradually sloping east coast $(B)$.

throat. The presence of pale lemon-yellow ventral coloration in the images of these live individuals indicates the ventral color recorded for the holotype (Figure $3 B$ ) was natural and not affected by freezing prior to preservation. Two juveniles observed (but not photographed) had a white color to the venter.

The individual in Figure $4 A$ shows nine upper labial scales on one side of the head and the individual in Figure 5 shows eight.

Distribution and Habitat: Île Walpole is an elongate raised limestone plateau $3-4 \mathrm{~km}$ in length and $300-800 \mathrm{~m}$ in width with steep cliffs falling to the sea (Figure $7 A$ and $B$ ).
Guano mining has degraded the southern and central parts of the central plateau (Sand 2004). Secondary bush formation (Leucaena leucocephala - a mimosoid tree) dominates most of the plateau in the north and south (Figure 8A), Pandanus tectorius spp. dominates the central plateau area (Figure $8 B$ ), and a well-preserved remnant of dry forest (Pisonia stand and Arytera forest with PandanusFigure $8 C$ ) is present on the far north of the plateau (Debar et al. 2013; Butaud and Jacq 2015). Epibator insularis n. sp. was found in all the major habitats surveyed on the island (Figure 9), although the two juveniles 

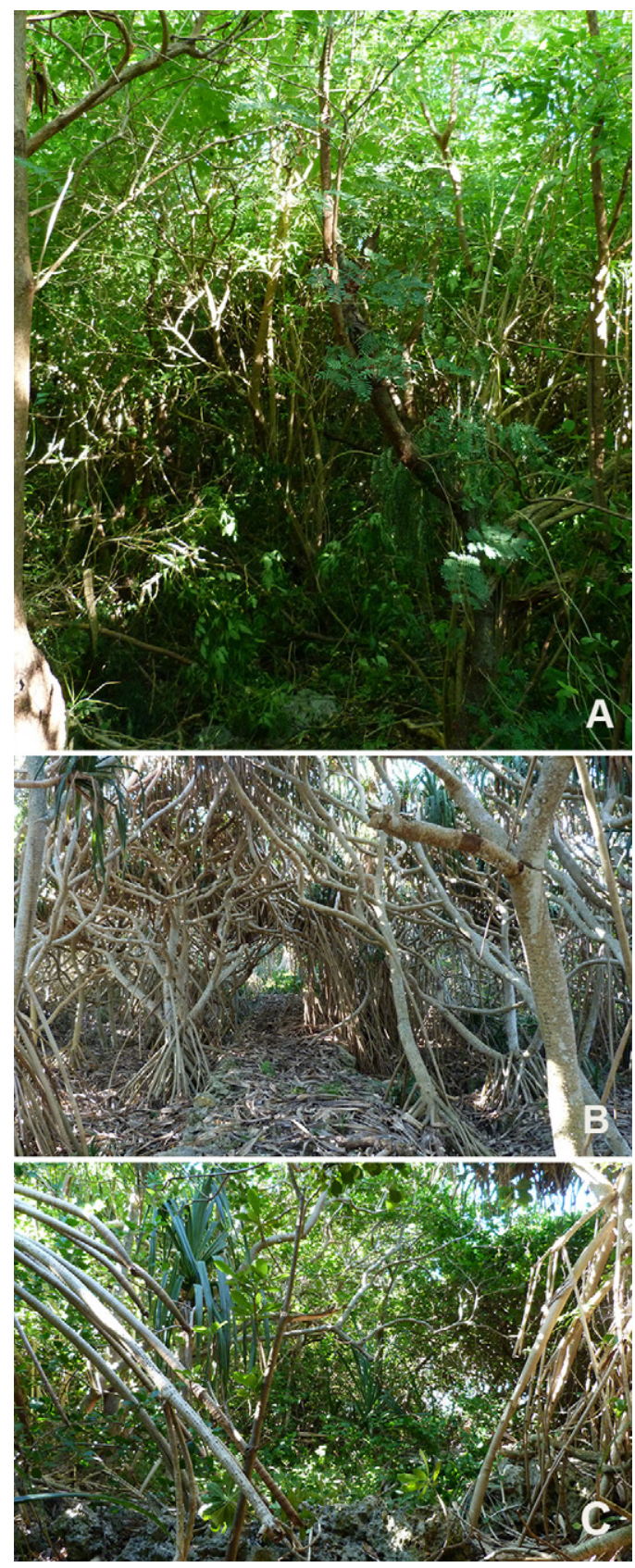

Figure 8. Habitats occupied by Epibator insularis n. sp.: Ssecondary mimosoid tree bush formation (Leucaena leucocephala) (A); Pandanus tectorius spp. $(B)$; remnant dry forest $(C)$.

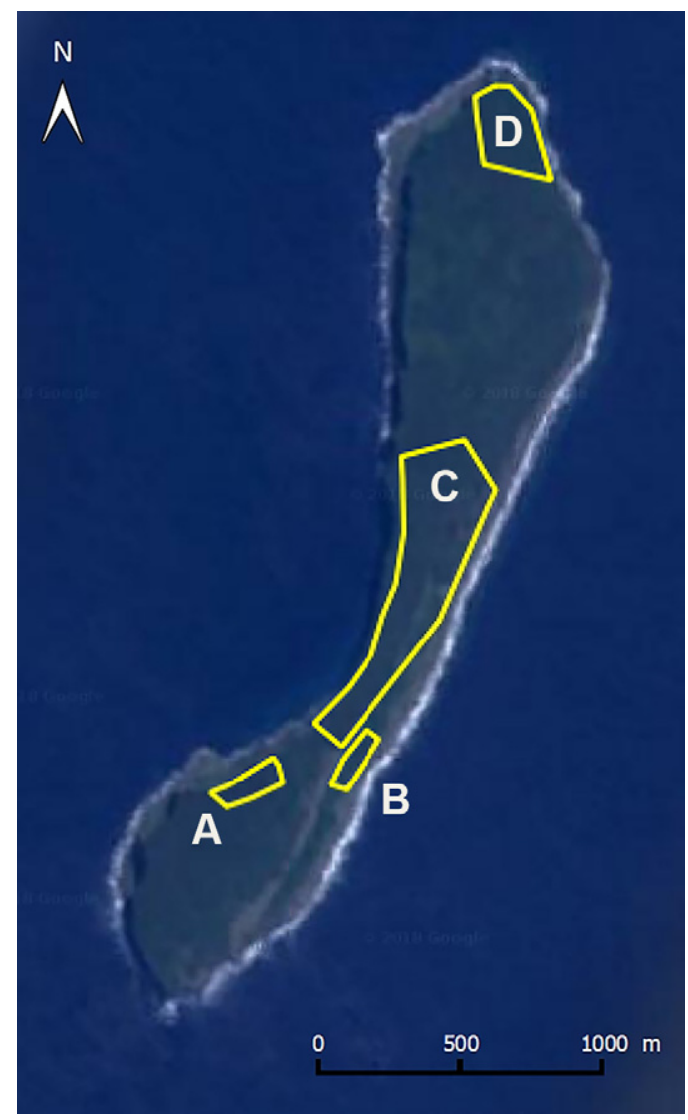

FIGURE 9. Areas formally surveyed for lizards on l'îlle Walpole in 2013. Epibator insularis n. sp. was recorded at four of five sites in secondary mimosoid formation in the southwest (area A); at two of three sites in natural forest on the southeast coast (area B); at all six sites surveyed in Pandanus on the central plateau (areaC); and at all four sites surveyed in natural forest in the north (area D).

recorded were found only in the relictual native forest in the north.

Biology: Most E. insularis n. sp. seen during the survey of Ille Walpole (LD) were initially observed on the ground, were wary when approached, and retreated to trees when disturbed, usually stopping a meter above ground level to observe the threat. Once on the tree they were more readily approached but would climb higher. However, it is possible the prevalence of on-ground behavior recorded to some extent represents a bias about when individuals were most obvious. Epibator insularis n. sp. was not observed on 
outcropping coralline cliffs of the coastline when these areas were visited opportunistically (the cliffs were not part of the survey regime). Epibator insularis n. sp. and Emoia cyanura (the only other skink on Ille Walpole) both occur in wooded habitat on the island, but no interaction was observed between the two species.

Many of the individuals observed had regenerated tails, indicating a high frequency of tail autotomy. Whether this is attributable to predation pressure from rats (many rats were observed in trees) or interactions between individual skinks remains to be established. An interesting aspect of behavior related to this observation was the unwillingness of skinks to autotomize their tails at capture, even when held only by the tail.

\section{DISCUSSION}

The presence on Île Walpole of an endemic lizard whose affinities clearly lie with congeners restricted to Grande Terre and islands of the region is at odds with the two other taxa of lizard recorded during the survey in March 2013, the skink Emoia cyanura and gekkonid gecko Lepidodactylus lugubris, both of which have widespread distributions throughout the west Pacific region. In New Caledonia Emoia cyanura has known resident populations on the Îles Loyauté, and the small gekkonid gecko Lepidodactylus lugubris has been recorded from most islands in the archipelago, including the Grande Terre.

The systematic status of the Emoia cyanura and Lepidodactylus lugubris populations on Île Walpole are unknown. Our ongoing studies (unpubl.) on Emoia cyanura in the Îles Loyauté indicates substantial genetic differentiation exists between populations on the islands of Lifou and Maré, and that these differ from populations in neighboring Vanuatu, indicating their origin on the Îles Loyauté was via natural dispersal rather than via humanmediated colonization. Lepidodactylus lugubris is a parthenogenetic species and a number of clones of them are known from the West Pacific (Ineich 1988, 1999). Clones A, B, C, D, and $\mathrm{E}$ of Lepidodactylus lugubris have all been recorded from New Caledonia, with A the most frequently encountered on both the Grande Terre and the Illes Loyauté (Ineich 1999; Bauer and Sadlier 2000), indicating human-mediated transfer. The identity of the Walpole populations of Emoia cyanura and Lepidodactylus lugubris requires further investigation to better understand the origin of the Walpole herpetofauna.

The objectives of the mission to Île Walpole in 2013 were to assess the presence of invasive species, with rats and ants of primary concern, and the status of terrestrial reptiles on the island (Debar et al. 2013). The Pacific Rat Rattus exulans (Peale) was the only rodent recorded on Walpole, with exceptionally large numbers trapped during the course of our field studies (80 specimens for 252 trap nights), the highest trapping densities being in the forested areas in the northern part of the plateau. A negative impact of Rattus exulans on island lizard populations has been documented, and recent studies in New Caledonia have identified it as significant predator of lizards (Jourdan et al. 2015; Thibault et al. 2017). Their presence suppresses potential lizard population densities, as evidenced by dramatic increases in lizard abundance in studies where management strategies have targeted rat reduction or elimination on islands (Monks et al. 2014). Epibator insularis n. sp. was recorded even in areas with high densities of rats. It is possible the high prevalence of individuals observed with regenerated tails may be a consequence of frequent encounters and predation pressure by rats. Even if not always resulting in mortality and immediate loss of individuals from the population, the impact of persistent nonlethal predation pressure could result in lowered fitness of individuals and indirectly affect population density.

Two species of highly invasive ants were recorded from scattered sites along the plateau, the Yellow Crazy Ant Anoplolepis gracilipes (Jerdon) and Little Red Fire Ant Wasmannia auropunctata (Roger). Another invasive ant Solenopsis geminata (Fabricius) is also known from previous visits on Walpole island (Jourdan and Mille 2006), but was not recorded during our survey, being associated with cliffs and open littoral areas, habitats not investigated in 2013. Wasmannia auropunctata 
has been identified as a serious environmental threat in the region (Jourdan 1997; Jourdan and Mille 2006), and has been demonstrated to have a negative impact on lizard population abundance in dry forest habitat (Jourdan et al. 2001) in New Caledonia. Booms in populations of Anoplolepis gracilipes have been flagged as a contributing factor in the crashes (and possible extinction) of lizard populations on Christmas Island in the Indian Ocean (Smith et al. 2012). The threats posed by these ants are complex (Jourdan et al. 2001, 2015; Le Breton et al. 2003; Gasc et al. 2018), but likely include the physical displacement lizards from sheltering and foraging sites by the presence of large numbers of ants during boom periods, and indirectly from loss and changes in composition of the invertebrate fauna that constitute a major part of the diet of lizards. On Walpole, Wasmannia auropunctata appears to have only been present for 20-30 years (Jourdan and Mille 2006), but the 2013 survey showed there to be an ongoing spread of this ant across all the habitats on the island. Although adult Epibator insularis n. sp. were observed in areas from which this ant was recorded, the only two juveniles found were from the more unaffected forest areas of the island. Anoplolepis gracilipes on the island appears to be more scattered in distribution, with less chance of deleterious interaction with Epibator insularis n. sp..

Epibator insularis n. sp. has an extremely small area of occupancy, which, in combination with the threats posed by the presence of high densities of Rattus exulans and the occurrence of the invasive ants Wasmannia auropunctata and (to a lesser extent) Anoplolepis gracilipes, place Epibator insularis n. sp. at high risk. The species would appear to satisfy the criteria for critically endangered under the IUCN Redlist classification system (IUCN 2017). It has a known area of occupancy estimated to be less than $10 \mathrm{~km}^{2}$ (criteria B2), is known only from a single location (criteria B2a) and by virtue of the documented impact of rats and invasive ants on lizards in the territory a decline in area, occurrence, occupancy, and extent and/or quality of habitat (criteria B2b i-iii), and in the number of mature individuals (criteria B2b iv-v) can reasonably be inferred, and is likely to be ongoing. The population status of Epibator insularis $\mathrm{n}$. sp. on Île Walpole urgently needs to be formally evaluated, as does the extent of occurrence and densities of Rattus exulans and invasive ants relative to that recorded in 2013.

\section{ACKNOWLEDGMENTS}

The authors thank the governement de la Nouvelle-Calédonie, through the Direction des Affaires Maritimes (DAM), especially Christophe Fonfreyde, for the opportunity to conduct field research on Île Walpole, and also the crew of Amborella, the boat from the DAM, for logistic support. Genetic work was funded by National Science Foundation Grant DEB 1555968 to AMB and by the Department of Biology, Villanova University. Images of live Epibator insularis n. sp. were taken by Léo Debar and of Epibator nigrofasciolatus by Ross Sadlier. The map for Figure 1 was provided by Jon DeBoer.

\section{Literature Cited}

Anderson, C. 1925. Notes on the extinct chelonian Meiolania, with a record of a new occurrence. Rec. Aust. Mus. 14 (4): 223-242 .

Andrews, E. C. 1922. Presidential address. J. Proc. R. Soc. N.S.W. 56:1-38.

Arevalo, E., S. K. Davis, and J. W. Sites, Jr. 1994. Mitochondrial DNA sequence divergence and phylogenetic relationships among eight chromosome races of the Sceloporus grammicus complex (Phrynosomatidae) in central Mexico. Syst. Biol. 43:387-418.

Bauer, A. M., T. Jackman, R. A. Sadlier, and A. H. Whitaker. 2006a. A revision of the Bavayia validiclavis group (Squamata: Gekkota: Diplodactylidae), a clade of New Caledonian geckos exhibiting microendemism. Proc. Calif. Acad. Sci. 57 (18): 503-547.

Bauer, A. M., T. Jackman, R. A. Sadlier and A. H. Whitaker. 2006b. A new genus and species of diplodactylid gecko (Reptilia: Squamata: Diplodactylidae) from 
northwestern New Caledonia. Pac. Sci. 60 (1): $125-135$.

Bauer, A. M., T. Jackman, R. A. Sadlier, and A. H. Whitaker. 2012. Revision of the giant geckos of New Caledonia (Reptilia: Diplodactylidae: Rhacodactylus). Zootaxa 3404:1-52.

Bauer A. M., and R. A. Sadlier. 1994. The terrestrial herpetofauna of the Île des Pins, New Caledonia. Pac. Sci. 48 (4): 353-366.

Bauer, A. M. and R. A. Sadlier. 2000. The Herpetofauna of New Caledonia. Society for the Study of Amphibians and Reptiles, Ithaca, NY) 310 pp., 24 pls.

Butaud, J. F. and F. Jacq. 2015. Parc naturel de la mer de corail - Îles éloignées. Guide floristique, Gouvernement de la NouvelleCalédonie, Nouméa. 126 pp.

Caesar, M., P. Grandcolas, R. Pellens. 2017. Outstanding micro-endemism in New Caledonia: More than one out of ten animal species have a very restricted distribution range. PLoS ONE 12 (7): e0181437. https://doi.org/10.1371/jour nal.pone. 0181437.

Chavis, M. A. 2016. Phylogeny and population genetics of New Caledonian geckos and skinks for the Isle of Pines region and Île Walpole. Unpublished M.S. Thesis. Villanova University, Villanova.

Cluzel, D., P. Maurizot, J. Collot, B. Sevin. 2012. An outline of the geology of New Caledonia; from Permian-Mesozoic southeast Gondwanaland active margin to Cenozoic obduction and supergene evolution. Episodes 35 (1): 72-79.

Daza, J. D., A. M. Bauer, C. Sand, I. Lilley, T. A. Wake, and F. Valentin. 2015. Reptile remains from Tiga (Tokanod), Loyalty Islands, New Caledonia 1. Pac. Sci. 69 (4): 531-557.

Debar, L., H. Jourdan, E. Vidal, and F. Rigault. 2013. Compte-rendu de la mission Walpole: Etat des lieux préliminaire de la faune de l'île et des menaces invasives (rongeurs et fourmis invasifs) Centre IRD de Noumea, Nouvelle-Calédonie: $14 \mathrm{pp}$.

Drummond, A. J., B. Ashton, S. Buxton, M. Cheung, A. Cooper, C. Duran, M. Field, J. Heled, M. Kearse, and S. Markowitz.
2012. Geneious Pro 5.6.7. https://www. geneious.com/.

Flecks, M., A. Schmitz, W. Böhme, F.-W. Henkel, and I. Ineich. 2012. A new species of Gebyra Gray, 1834 (Squamata, Gekkonidae) from the Loyalty Islands and Vanuatu, and phylogenetic relationships in the genus Gebyra in Melanesia. Zoosystema 34:203-221.

Gaffney, E. S. 1996. The postcranial morphology of Meiolania platyceps and a review of the Meiolaniidae. Bull. Am. Mus. Nat. Hist. 229:1-165.

Gaffney, E. S., J.-C. Balouet, and F. de Broin. 1984. New occurrences of extinct meiolaniid turtles in New Caledonia. Am. Mus. Novit. 2800:1-6.

Gasc, A., J. Anso, J. Sueur, H. Jourdan, L. Desutter Grandcolas. 2018. Cricket calling communities as an indicator of the invasive ant Wasmannia auropunctata in an insular biodiversity hotspot. Biol. Invasions 20 (5): 1099-1111.

Geneva, A. 2007. The phylogeography of Bavayia cf. crassicollis. Unpublished M.S. Thesis. Villanova University, Villanova.

Geneva, A., A. M. Bauer, R. A. Sadlier, and T. R. Jackman. 2013. Terrestrial herpetofauna of Île des Pins, New Caledonia, with an emphasis on its surrounding islands. Pac. Sci. 67 (4): 571-590.

Greenbaum, E., A. M. Bauer, T. R. Jackman, M. Vences, and R. Glaw. 2007. A phylogeny of the enigmatic Madagascan geckos of the genus Uroplatus (Squamata: Gekkonidae). Zootaxa 1493:41-51.

Ineich, I. 1988. Mise en évidence d'un complexe unisexué-bisexué chez le Gecko Lepidodactylus lugubris (Sauria, Lacertilia) en Polynésie française. C. r. Acad. Sci. 307, Série III: 271-277.

Ineich, I. 1999. Spatio-temporal analysis of the unisexual-bisexual Lepidodactylus lugubris complex (Reptilia, Gekkonidae). In: Tropical Island Herpetofauna: Origin, Current Diversity, Conservation, p., 199-228., Ota, H., Ed., Amsterdam, Elsevier.

Ineich, I., 2009. Bocourt's terrific skink, Phoboscincus bocourti Brocchi, 1876 (Squamata, Scincidae, Lygosominae). In Grandcolas P. 
(ed.), Zoologia Neocaledonica, 7. Biodiversity studies in New Caledonia. Mém. Mus. Natl. Hist. Nat. 198:149-174.

Ineich, I., R. Sadlier, A. M. Bauer, T. R. Jackman, and S. A. Smith. 2014. Bocourt's terrific skink, Phoboscincus bocourti (Brocchi, 1876), and the monophyly of the genus Phoboscincus Greer, 1974. In Guilbert, É., Robillard, T., Jourdan, H. \& Grandcolas, P. (eds.), Zoologia Neocaledonica 8. Biodiversity studies in New Caledonia. Mém. Mus. Natl. Hist. Nat. 206:69-79.

IUCN. 2017. The IUCN Red List of Threatened Species 2001 Categories \& Criteria (version 3.1). http://www.iucnred list.org/technical-documents/categoriesand-criteria/2001-categories-criteria.

Jourdan, H. 1997. Threats on Pacific islands: The spread of the tramp ant Wasmannia auropunctata (Hymenoptera: Formicidae). Pac. Conserv. Biol. 3:61-64.

Jourdan, H. and C. Mille. 2006. Les invertébrés introduits dans l'archipel néo-calédonien: espèces envahissantes et potentiellement envahissantes. Première évaluation et recommandations pour leur gestion. Cédérom: 168-219. In «Espèces envahissantes: risque environnemental et socioéconomiquemajeurs pour l'archipel néo-calédonien», $M$. L. Beauvais, A. Coleno, and H. Jourdan (Eds). Coll. Expertise Collégiale, IRD Editions, Paris, 260 pp. + cédérom.

Jourdan, H., F. Brescia, and E. Vidal. 2015. Impact des espèces invasives sur les reptiles des massifs miniers. Rapport Scientifique CNRT/IRD/IAC. 91 pp.

Jourdan, H., R. A. Sadlier, and A. M. Bauer. 2001. Little Fire Ant invasion (Wasmannia auropunctata) as a threat to New Caledonian Lizards: Evidences from a sclerophyll forest (Hymenoptera: Formicidae). Sociobiology 38 (3A): 283-301.

Katoh, K., K. Misawa, K.-i. Kuma, and T. Miyata. 2002. MAFFT: A novel method for rapid multiple sequence alignment based on fast Fourier transform. Nucleic Acids Res. 30:3059-3066.

Lanfear, R., B. Calcott, D. Kainer, C. Mayer, and A. Stamatakis. 2014. Selecting optimal partitioning schemes for phylogenomic datasets. BMC Evol. Biol. 14:82.

Le Breton, J., J. Chazeau, H. Jourdan. 2003. Immediate impacts of invasion by Wasmannia auropunctata (Hymenoptera: Formicidae) on native litter ant fauna in a New Caledonian rain forest. Austral Ecol. 28:204-209.

Macey, J. R., A. Larson, N. B. Ananjeva, Z. Fang, and T. J. Papenfuss. 1997. Two novel gene orders and the role of light-strand replication in rearrangement of the vertebrate mitochondrial genome. Mol. Biol. Evol. 14:91-104.

Miller, M. A., W. Pfiefer, and T. S. Schwartz. 2010. Creating the CIPRES Science Gateway for inference of large phylogenetic trees. Proceedings of the Gateway Computing Environments Workshop (GCE) 2010, pp. 1-8.

Monks, J. M., A. Monks, and D. R. Towns. 2014. Correlated recovery of five lizard populations following eradication of invasive mammals. Biol. Invasions 16:167-175.

Paris, J. P. 1981. Géologie de la NouvelleCalédonie. Mémoires du Bureau de Recherches Géologiques et Minières 113:1$-278,2$ separate maps.

Portik, D. M., A. M. Bauer, and T. R. Jackman. 2010. The phylogenetic affinities of Trachylepis sulcata nigra and the intraspecific evolution of coastal melanism in the western rock skink. Afr. Zool. 45:147-159.

Rambaut, A., A. J. Drummond, and M. Suchard. 2007. Tracer v1.6. http://tree. bio.ed.ac.uk/software/tracer/.

Renevier, A. and J. F. Cherrier. 1991. Flora and vegetation of Walpole Island. Atoll Res. Bull. 351:1-21.

Ronquist, F. and J. P. Huelsenbeck. 2003. MrBayes 3: Bayesian phylogenetic inference under mixed models. Bioinformatics 19:1572-1574.

Sadlier, R. A. 1986. A review of the scincid lizards of New Caledonia. Rec. Aust. Mus. 39:1-66.

Sadlier, R. A. 2010. Systematic studies of the scincid lizards of New Caledonia. Unpublished PhD. Thesis, Griffith University, Queensland. 199 pp. 
Sadlier, R. A. and A. M. Bauer. 1997. The terrestrial herpetofauna of the Loyalty Islands. Pac. Sci. 51 (1): 76-90.

Sadlier R. A. and A. M. Bauer, 1999. The scincid lizard genus Sigaloseps (Reptilia: Scincidae) from New Caledonia in the southwest Pacific: description of a new species and review of the biology, distribution, and morphology of Sigaloseps deplanchei (Bavay). Rec. Aust. Mus. 51 (1): 83-91.

Sadlier, R. A. and A. M. Bauer. 2000. The scincid lizard genus Marmorosphax (Reptilia: Scincidae) from New Caledonia in the southwest Pacific: Description of a new species restricted to high-altitude forest in Province Sud. Pac. Sci. 54 (1): 56-62.

Sadlier, R. A., A. M. Bauer, and S. A. Smith. 2006. A new species of Nannoscincus Günther (Squamata: Scincidae) from high elevation forest in southern New Caledonia. Rec. Aust. Mus. 58:29-36.

Sadlier, R. A., A. M., Bauer, G. M. Shea, and S. A. Smith. 2015. Taxonomic resolution to the problem of polyphyly in the New Caledonian scincid lizard genus Lioscincus (Squamata: Scincidae). Rec. Aust. Mus. 67 (7): 207-224.

Sadlier, R. A., A. M. Bauer, and A. H. Whitaker. 2002. The scincid lizard genus Nannoscincus Gunther from New Caledonia in the southwest Pacific: a review of the morphology and distribution of species in the Nannoscincus mariei species group, including the description of three new species from Province Nord. In Najt J \& Grandcolas P (eds), Zoologia Neocaledonica 5, Mém Mus Natl Hist Nat 87:233-255 Paris

Sadlier, R. A., A. M. Bauer, A. H. Whitaker, and S. A. Smith. 2004. Two new species of scincid lizards (Squamata) from the Massif de Kopéto, New Caledonia. Proc. Calif. Acad. Sci. 55 (11): 208-221.

Sadlier, R. A., A. M. Bauer, P. L. Jr. Wood, S. A. Smith, and T. R. Jackman. 2013. A new species of lizard in the genus Caledoniscincus (Reptilia: Scincidae) from southern New Caledonia and a revision of Caledoniscincus atropunctatus (Roux). Zootaxa 3694 (6): 501-524.
Sadlier, R. A., A. M. Bauer, P. L. Jr Wood, S. A. Smith, A. H. Whitaker, H. Jourdan, and T. Jackman. 2014. Localized endemism in the southern ultramafic bio-region of New Caledonia as evidenced by the lizards in the genus Sigaloseps (Reptilia: Scincidae), with descriptions of four new species. In Guilbert, É., Robillard, T., Jourdan, H. \& Grandcolas, P. (eds), Zoologia Neocaledonica 8. Biodiversity studies in New Caledonia. Mém. Mus. Natl. Hist. Nat. 206:79-113.

Sadlier, R. A., M. Deuss, A. M. Bauer, H. Jourdan. 2019 A new genus and species of scincid lizard from the Ile des Pins, New Caledonia, with comments on the diversity and affinities of the region's lizard fauna. Pac. Sci.: 73(1): 121-39.

Sadlier, R. A., S. A. Smith, and A. M. Bauer. 2006. A new genus for the New Caledonian scincid lizard Lygosoma euryotis Werner 1909 , and the description of a new species. Rec. Aust. Mus. 58: 19-28.

Sadlier, R. A., S. A. Smith, A. M. Bauer and A. H. Whitaker. 2004. A new genus and species of live-bearing scincid lizard (Reptilia: Scincidae) from New Caledonia. J. Herp. 38(3): 320-330.

Sadlier, R. A., S. A. Smith, A. M. Bauer, and A. H. Whitaker. 2009. Three new species of skink in the genus Marmorosphax Sadlier (Squamata: Scincidae) from New Caledonia. In Grandcolas P. (ed.), Zoologia Neocaledonica 7. Biodiversity studies in New Caledonia. Mém. Mus. Natl. Hist. Nat. 198:373-390. Paris.

Sadlier, R. A., A. H., Whitaker, P. L. Jr. Wood, and A. M. Bauer. 2014. A new species of lizard in the genus Caledoniscincus (Reptilia: Scincidae) from far northwest New Caledonia. Zootaxa 3795 (1): 45-60.

Sanchez, M., J-J. Cassan, and T. Duval. 2015. A new locality for Correlophus ciliatus and Rhacodactylus leachianus (Sauria: Diplodactylidae) from Néhoué River, northern New Caledonia. Herpetol. Notes 8:553-555 .

Sand, C. 2004. Walpole, a "mystery island" in southeast New Caledonia? Rec. Aust. Mus. Supp. 29:109-122. 
Skipwith, P., T. Jackman, A. H. Whitaker, A. M. Bauer, and R. A. Sadlier. 2014. New data on Dierogekko (Squamata: Gekkota: Diplodactylidae), with the description of a new species from Ille Baaba, Province Nord, New Caledonia. In É Guilbert, T. Robillard, H. Jourdan, and P. Grandcolas (eds.), Zoologia Neocaledonica 8. Biodiversity studies in New Caledonia. Mém. Mus. Natl. Hist. Nat. 206:3-30.

Smith, M. J., H. Cogger, B. Tiernan, D. Maple, C. Boland, F. Napier. 2012. An oceanic island reptile community under threat: the decline of reptiles on Christmas Island, Indian Ocean. Herpetological Conserv. Biol. 7:206-218.

Smith, S. A., R. A. Sadlier, A. M. Bauer, C. C. Austin, and T. Jackman. 2007. Molecular phylogeny of the scincid lizards of New Caledonia and adjacent areas: Evidence for a single origin of the endemic skinks of Tasmantis. Mol. Phylogenet. Evol. 43:1151-1166.

Stamatakis, A. 2006. RAxML-VI-HPC: maximum likelihood-based phylogenetic analyses with thousands of taxa and mixed models. Bioinformatics 22:2688-2690.

Stamatakis, A., P. Hoover, and J. Rougemont. 2008. A rapid bootstrap algorithm for the RAxML web servers. Syst. Biol. 57:758-771 .

Thibault, M., F. Brescia, H. Jourdan, and E. Vidal. 2017. Invasive rodents, an overlooked threat for skinks in a tropical island hotspot of biodiversity. N. Z. J. Ecol. 41(1): 74-83. doi:10.20417/nzjecol.41.9. 